\title{
Tailoring of drug delivery of 5-fluorouracil to the colon via a mixed film coated unit system
}

RUCHITA V. KUMAR

VIVEK RANJAN SINHA*

University Institute of Pharmaceutical Sciences, Panjab University

Chandigarh-160014, India
The study was carried out to establish the effectiveness of a mixed film composed of ethylcellulose/Eudragit S100 for colonic delivery of 5-flourouracil (5-FU). Tablets cores containing 5-FU were prepared by direct compression method by coating at different levels $(2-9 \%, \mathrm{~m} / \mathrm{m})$ with a non-aqueous solution containing ethylcellulose/ Eudragit S100. Coated tablets were studied for the in vitro release of 5-FU and the samples were analyzed spectrophotometrically at $266 \mathrm{~nm}$. Drug release from coated systems depended on the thickness of the mixed film and the composition of the core. Channel formation was initiated in the coat by dissolution of the Eudragit S100 fraction at higher $\mathrm{pH}$ in the colonic region. The release was found to be higher in tablets containing Avicel as filler owing to its wicking action compared to that from lactose containing cores. Furthermore, batches containing superdisintegrant $(1 \%, \mathrm{~m} / \mathrm{m}$ Cross-PVP) along with Avicel in the core released approximately $81.1 \%$ drug during the colonic transit time. Kinetic studies indicated that all the formulations followed first-order release kinetics. The developed delivery system will expectedly deliver the drug to the colon.

Keywords: 5-flourouracil, ethylcellulose, Eudragit-S100, Cross-polyvinylpyrrolidone, lactose, Avicel

Colorectal cancer is the third most common cause of cancer deaths all over the globe. The most extensively exploited formulation strategy for colon targeted drug delivery systems (CDDS) has been the employment of enteric coatings. The $\mathrm{pH}$ differential in the different segments of the gastrointestinal tract is the basic triggering factor for $\mathrm{pH}$ -sensitive polymers. The release through these systems also depends on the transit time of the formulation through the small intestine $(1,2)$. Thus, an optimized enteric coat is desired for drug release in the colon. The site of drug release is tailored by modulating the thickness of the coat (3). For the purpose of targeting drugs to the colon, the solid dosage forms such as tablets, microparticulates, capsules and pellets are generally coa-

\footnotetext{
* Correspondence; e-mail: sinha_vr@rediffmail.com
} 
ted with a $\mathrm{pH}$-sensitive polymer. These are the preferred pharmaceutical dosage forms due to their relatively low cost of production and the ease of manufacture compared to other more complex delivery systems (4). Much emphasis is currently being laid on the development of mixed film coated systems, in which a combination of a release retardant hydrophobic material and a hydrophilic material is employed to exploit the desired benefits of each. The rationale behind adding a water-soluble fraction to the coat is to assist in the generation of aqueous channels after a desired lag phase. These aqueous pores help drug release in the colon. Various reports discussing the importance of the use of polysaccharides as the desired hydrophilic pore formers have been published to date (5, 6). Wackerly and co-workers (7) have studied in detail the effect of mixed films composed of ethylcellulose and pectin on the colonic delivery of paracetamol. As ethylcellulose is a hydrophobic polymer, addition of a hydrophilic fraction to the coat results in site-specific delivery of the drug through the aqueous pores formed by dissolution of the pectin fraction of the film in the last segment of the GIT due to activity of pancreatic enzymes.

The objective of the present study was to develop a novel mixed film coated system composed of an appropriate combination of a hydrophobic polymer (e.g., ethylcellulose) and an enteric polymer (e.g., Eudragit S100) to achieve maximal drug release in the proximal segment of the colon. Considering the high applicability and usefulness of enteric polymers in the development of CDDSs, an enteric polymer was selected as the pore former in the study. 5-Fluorouracil (5-FU) was chosen as the model drug. 5-FU is one of the most widely used agents in the first-line chemotherapy of colorectal cancer (8). As 5-FU is an extremely water soluble moiety, premature release of the drug in the upper segment of the GIT is associated with many deleterious effects. Site-specific delivery of 5-FU to the colon will also overcome the side-effects associated with the parenteral delivery of the drug, which includes gastrointestinal toxicity, hematological and neural disorders and cardiac manifestations (9). Furthermore, to achieve complete release of the drug candidate at the site of action a small concentration of superdisintegrant (Cross-PVP) was also introduced into the core (10). The influence of using various fillers, viz., spray dried lactose and Avicel, was also studied.

\section{EXPERIMENTAL}

\section{Preparation of 5-FU core tablets}

Core tablets containing $250 \mathrm{mg}$ of 5-FU were prepared by conventional direct compression of the drug with different fillers, viz., spray dried lactose (SDL) and microcrystalline cellulose (Avicel PH102). Batches containing two different levels of Cross-PVP as superdisintegrant were also prepared. Magnesium stearate $(1 \%)$ and talc $(2 \%)$ were used as glidant and lubricant, respectively. Weighed quantities of excipients were thoroughly mixed with the drug by geometric addition in a mortar for about 10 minutes. Pre-sieved magnesium stearate and talc were then added and further blended for 2 minutes. The homogeneous mixture thus obtained was weighed individually (350 mg) and fed manually into the die of a single punch tablet machine (Modern Engineering, India) equipped with 9.7-mm deep concave punches. 
R. V. Kumar and V. R. Sinha: Tailoring of drug delivery of 5-fluorouracil to the colon via a mixed film coated unit system, Acta Pharm. 61 (2011) 343-351.

\section{Preparation of coating solution}

The coating solution $(6.0 \%, \mathrm{~m} / \mathrm{V})$ containing ethylcellulose/Eudragit S100 in the ratio 1:1 was prepared in a mixture of ethanol and isopropyl alcohol (1:3) using dibutyl phthalate $(10 \%, \mathrm{~m} / \mathrm{m})$ as the plasticizer. The solution was stirred on a mechanical stirrer for a sufficient period of time to obtain a clear solution.

\section{Coating of the core tablets}

All the batches were coated at different levels in the range from 2 to $9 \%, \mathrm{~m} / \mathrm{m}$ of the initial tablet mass, using the pan coating method and dried with hot air with an inlet air temperature of $35-45^{\circ} \mathrm{C}$. The coating process was continued in order to obtain the desired level of coat mass. The percent coat mass gain (CMG) for all the bathes is given in Table I.

Table I. Composition of various batches

\begin{tabular}{ccccc}
\hline Batch code & SDL $(\mathrm{mg})$ & Avicel PH102 $(\mathrm{mg})$ & Cross-PVP $(\mathrm{mg})$ & Coat mass gain $(\%)$ \\
\hline MF1A & 89.5 & - & - & 1.8 \\
MF1B & 89.5 & - & - & 3.9 \\
MF1C & 89.5 & - & - & 5.3 \\
MF2A & - & 89.5 & - & 2.2 \\
MF2B & - & 89.5 & - & 4.0 \\
MF2C & - & 89.5 & - & 6.2 \\
MF3A & - & 86.0 & 3.5 & 1.7 \\
MF3B & - & 86.0 & 3.5 & 5.8 \\
MF3C & - & 86.0 & 3.5 & 8.4 \\
\hline
\end{tabular}

*All the batches contained $250 \mathrm{mg}$ of 5 -FU and the final mass of each tablet was $350 \mathrm{mg}$.

\section{In vitro release studies}

To study the in vitro release profile of the drug, the dissolution test was carried out on all the formulations according to the USP 27 (11) method for delayed release tablets (method A). Dissolution studies were carried out using a USP apparatus type-II, i.e., paddle type, at $50 \mathrm{rpm}$ and at a temperature of $37 \pm 0.5^{\circ} \mathrm{C}$. Initial studies were carried out in $750 \mathrm{~mL}$ of $0.1 \mathrm{~mol} \mathrm{~L}^{-1} \mathrm{HCl}(\mathrm{pH} 1.2)$ for 2 hours, followed by addition of $250 \mathrm{~mL}$ of 0.2 mol L-1 trisodium orthophosphate, in order to obtain a final $\mathrm{pH}$ of 6.8 in the medium. Samples were withdrawn at predetermined time intervals and replaced with fresh media for $24 \mathrm{~h}$. All the dissolution studies were performed in triplicate, i.e., three tablets representative of each batch were studied. They were then analyzed using a UV-spectrophotometer (Shimadzu-1601, Japan) at $\lambda_{\max }$ of $266 \mathrm{~nm}$. 
R. V. Kumar and V. R. Sinha: Tailoring of drug delivery of 5-fluorouracil to the colon via a mixed film coated unit system, Acta Pharm. 61 (2011) 343-351.

\section{Drug release kinetics}

In order to study the mechanism of drug release from the prepared matrix tablets, the release data obtained was evaluated using zero-order release kinetics (Eq. 1), first order kinetics (Eq. 2), Higuchi's square root of time equation (Eq. 3) (12), Korsemeyer and Peppas equation (Eq. 4) (13) and Hixon-Crowell's cube root of time equation (Eq. 5) (14).

$$
M_{\mathrm{t}}=M_{0}+k_{0} t
$$

where $M_{\mathrm{t}}$ is the amount of drug dissolved in time $t, M_{0}$ is the initial amount of drug in the solution, $k_{0}$ is the zero-order release rate constant and $t$ is the release time,

$$
M_{\mathrm{t}}=M_{0} \mathrm{e}^{-k t}
$$

where $M_{\mathrm{t}}$ is the amount of drug dissolved in time $t, M_{0}$ is the initial amount of drug in the solution, $k$ is the first-order release rate constant and $t$ is the release time,

$$
M_{\mathrm{t}}=k_{\mathrm{h}} \sqrt{t}
$$

where $M_{\mathrm{t}}$ is the amount of drug dissolved in time $t, k_{\mathrm{h}}$ is the Higuchi dissolution constant and $t$ is the release time,

$$
M_{\mathrm{t}} / M_{\infty}=k t^{\mathrm{n}}
$$

where, $M_{\mathrm{t}}$ and $M_{\infty}$ are the cumulative amount of drug released at time $t$ and infinite time, respectively; $k_{\mathrm{s}}$ is a constant incorporating structural and geometric characteristics of the device, and $n$ is the drug release exponent, indicative of the mechanism of drug release. The values of $n$ assigned to a cylinder are 0.45 for Fickian diffusion and $0.45<n$ $<0.89$ for non-Fickian diffusion, respectively.

$$
M_{0}^{1 / 3}-M_{\mathrm{t}}^{1 / 3}=k_{\mathrm{s}} t
$$

where $M_{0}$ is the initial amount of drug in the formulation, $M_{\mathrm{t}}$ is the amount remaining at any time $t$ and $k_{\mathrm{s}}$ is the constant incorporating the surface-volume relation, in the Hixon-Crowell model. 
R. V. Kumar and V. R. Sinha: Tailoring of drug delivery of 5-fluorouracil to the colon via a mixed film coated unit system, Acta Pharm. 61 (2011) 343-351.

\section{RESULTS AND DISCUSSION}

\section{Physical Evaluation}

The tablets showed good hardness $\left(6-8 \mathrm{~kg} \mathrm{~cm}^{-2}\right)$ and low friability $(<0.3 \%)$. The concentration of 5-FU in all the batches was $71.4 \%(\mathrm{~m} / \mathrm{m})$. All the prepared batches passed the uniformity of concentration test with $99.9 \pm 0.6 \%$ of absolute concentration. Disintegration time of the coated tablets was recorded in phosphate buffer $(\mathrm{pH} 6.8)$. The core tablets containing SDL disintegrated within 15 minutes; however the batches containing MCC PH102 disintegrated into fragments within 5 minutes. This is attributed to the fast wicking rate of MCC for water which aids in rapid disintegration of tablet formulations (15). The uncoated tablet cores containing $1 \%$ Cross-PVP disintegrated more rapidly, within 2.75 minutes. However, the coated tablets remained intact when exposed to disintegration studies for $2 \mathrm{~h}$ in $0.1 \mathrm{~mol} \mathrm{~L}^{-1} \mathrm{HCl}$ followed by $1 \mathrm{~h}$ in phosphate buffer ( $\mathrm{pH}$ 8), indicating the effectiveness of the coat.

\section{In vitro release}

The in vitro release data obtained indicated that the rate of release of 5-FU is inversely proportional to the thickness of the coat, suggesting that the film coat controls the release process. The initial stage of drug release is probably due to the slow diffusion through the ethylcellulose phase. The main reason proposed for the rise in drug release after $6 \mathrm{~h}$ is the formation of aqueous pores in the film due to dissolution or the Eudragit $\mathrm{S} 100$ fraction at an alkaline $\mathrm{pH}$ in the intestine. The core excipients used in the current study also had a significant impact on the dissolution rate of the drug. Lack of drug release (i.e., $<4 \%$ in $24 \mathrm{~h}$ ) was observed in batches MF1A, B and C, containing SDL as filler. The in vitro release profiles of batches MF2A, MF2B and MF2C containing Avicel as filler indicated satisfactory results by preventing premature drug release in the initial segment of the GIT to less than $2 \%$ in the initial $6 \mathrm{~h}$, followed by significant release in the colon. The results for dissolution studies carried out on various formulations are shown in Fig. 1a. This increase in 5-FU release in the last segment of the study is due to the formation of a channel in the coat due to the dissolution of the Eudragit S100 fraction in the alkaline microenvironment of the large intestine. Dissolution of this fraction of the film generates pores which aid in the percolation of the media inside the core and dissolution of the drug. Thus, after $10 \mathrm{~h}, 22.5 \pm 0.1,19.3 \pm 1.1$ and $2.9 \pm 0.1 \%$ of 5 -FU was released from batches MF2A, MF2B and MF2C, respectively. At the end of $24 \mathrm{~h}$, approximately $47.2 \pm 0.6,34.6 \pm 1.1$ and $12.0 \pm 0.4 \%$ of the drug was released from batches MF2A, MF2B and MF2C, respectively. Thus, MF2A formulation had a significantly higher release of 5-FU compared to all the other formulations tested. It was concluded that Avicel acted as a disintegrating agent within these ethylcellulose/Eudragit-S100 film structures. Owing to its fast wicking rate for water, it aids in faster disintegration of tablet formulations (16). However, in spite of the initial retardation, the Avicel cores were not able to release the drug completely. To overcome this limitation and to achieve a complete release of 5-FU in the colonic region, a small amount of superdisintegrant was added to the core. 
R. V. Kumar and V. R. Sinha: Tailoring of drug delivery of 5-fluorouracil to the colon via a mixed film coated unit system, Acta Pharm. 61 (2011) 343-351.

a)

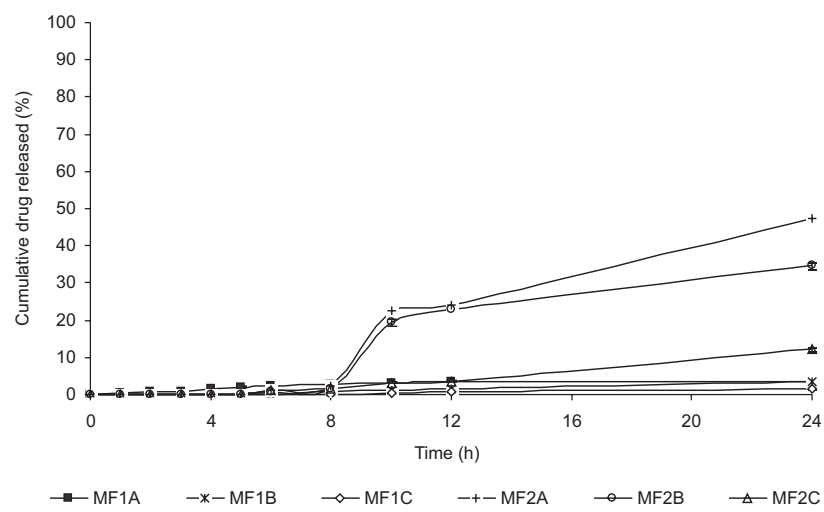

b)

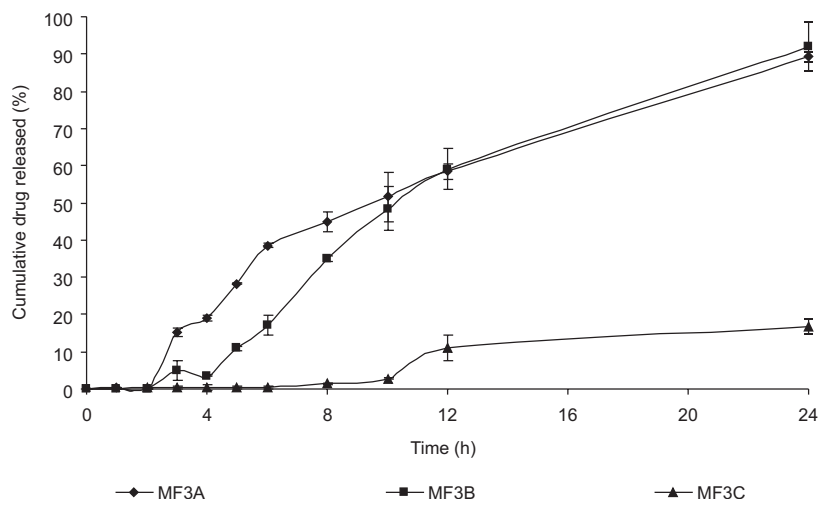

Fig. 1. Cumulative percent release of 5-fluorouracil coated at three levels with a mixture of ethylcellulose/Eudragit-S100 (1:1) from: a) core tablets containing different fillers, viz., spray dried lactose (MF1A-C) and Avicel (MF 2A-C) and b) from superdisintegrant containing core tablets coated at three levels (MF 3A-C). Mean \pm SD, $n=3$.

\section{Effect of superdisintegrant}

Cross-PVP ( $1 \%$ ) was added as a superdisintegrant to the tablet core containing Avicel as filler in order to increase drug release by rapid bursting of the tablet in the colonic region. Tablets containing $1 \%, m / V$, Cross-PVP in the core were coated with a blend of ethylcellulose/Eudragit-S100 (1:1) at three different levels (MF3A, MF3B and MF3C). The cumulative percent release observed for the batches is shown in Fig. 1b. Optimum release profile was obtained for batch MF3B, containing $1 \%$ cross-PVP, Avicel and coated with $5.8 \%(m / V)$ of ethylcellulose/Eudragit S100 (1:1). This formulation showed $10.9 \pm 7.6 \%$ release in the initial 5 hours followed by approximately $80 \%$ release during the colon transit time, i.e., from 5 to $24 \mathrm{~h}$. It was postulated that the $\mathrm{pH}$-dependent dissolution of the Eudragit-S100 fraction generates pores in the film structure through which 
R. V. Kumar and V. R. Sinha: Tailoring of drug delivery of 5-fluorouracil to the colon via a mixed film coated unit system, Acta Pharm. 61 (2011) 343-351.

the dissolution medium percolates into the core and interacts with the superdisintegrant present in the core. The superdisintegrant has the tendency to absorb aqueous fluids quickly, which results in bursting of the drug release from the tablet at latter time points. This ensures complete drug release in the colonic segment of the GIT.

\section{Kinetics of drug release}

Values of the coefficient of determination for all the release models obtained are as given in Table II. A comparative study of these values clearly showed that the first-order model was the best-fit model for all the batches prepared during the study irrespective of the nature of the filler or the presence or absence of the superdisintegrant. The values of regression in the first-order model (i.e., $R^{2}$ ) were close to unit in all cases. This is attributed to the dissolution of the Eudragit S100 fraction of the film, which leads to the formation of aqueous pores that facilitate drug dissolution proportional to the concentration of the drug present in the core. Typically, all the water soluble drugs generally follow the first-order release mechanism (17).

Table II. Comparative characteristics of different drug release models from various coated batches

\begin{tabular}{cccccc}
\hline \multirow{2}{*}{$\begin{array}{c}\text { Batch } \\
\text { code }\end{array}$} & \multicolumn{5}{c}{$R^{2}$ for release model } \\
\cline { 2 - 6 } & Zero-order & First-order & Higuchi & Korsmeyer-Peppas & Hixson-Crowell \\
\hline MF1A & 0.615 & 0.956 & 0.540 & 0.795 & 0.597 \\
MF1B & 0.615 & 0.993 & 0.511 & 0.880 & 0.845 \\
MF1C & 0.960 & 0.968 & 0.415 & 0.910 & 0.881 \\
MF2A & 0.912 & 0.951 & 0.474 & 0.814 & 0.740 \\
MF2B & 0.829 & 0.867 & 0.472 & 0.784 & 0.679 \\
MF2C & 0.980 & 0.987 & 0.452 & 0.647 & 0.816 \\
MF3A & 0.973 & 0.988 & 0.931 & 0.973 & 0.917 \\
MF3B & 0.922 & 0.997 & 0.696 & 0.892 & 0.790 \\
MF3C & 0.883 & 0.891 & 0.443 & 0.896 & 0.819 \\
\hline
\end{tabular}

\section{CONCLUSIONS}

The present findings suggest that the developed mixed film coated system exploits the benefits offered by both polymers used in the film. Both ethylcellulose and Eudragit S100 synergistically prevent premature release of 5-FU owing to their hydrophobicity and $\mathrm{pH}$ dependent solubility, respectively. The presence of Eudragit S100 simply accelerates pore formation by dissolving in the alkaline $\mathrm{pH}$ and therefore enhancing release of 5-FU in the colonic region. In addition, there is probably a significant contribution from the superdisintegrant as the drug/excipient core gradually dissolves. The results of this study have shown that ethylcellulose/Eudragit S100 combinations, when used as film coating agents, may be valuable in colonic drug delivery. 
R. V. Kumar and V. R. Sinha: Tailoring of drug delivery of 5-fluorouracil to the colon via a mixed film coated unit system, Acta Pharm. 61 (2011) 343-351.

\section{REFERENCES}

1. R. Kinget, K. Willbrord, V. Liesbeth and G. Van den Mooter, Colonic drug targeting, J. Drug Target. 6 (1998) 129-149; DOI: 10.3109/10611869808997888.

2. C. S. Leopold and D. Eikeler, Basic coating polymers for the colon-specific drug delivery in inflammatory bowel disease, Drug Dev. Ind. Pharm. 26 (2000) 1239-1246; DOI: 10.1081/DDC-100102305.

3. T. Ishibashi, H. Hatano, M. Kobayashi, M. Mizone and M. Yoshino, Design and evaluation of a new capsule-type dosage form for colon-targeted delivery of drugs, Int. J. Pharm. 168 (1998) 31-40; DOI: 10.1016/S0378-5173(98)00082-9.

4. D. R. Friend, New oral delivery systems for treatment of inflammatory bowel disease, Adv. Drug Del. Rev. 57 (2005) 247-265; DOI: 10.1016/j.addr.2004.08.011.

5. F. Li-Fang, H. Wei, B. Min, D. Qing, X. Bai, C. Yong-Zhen and C. De-Ying, Biphasic drug release: permeability and swelling of pectin/ethyl cellulose films, and in vitro and in vivo correlation of film-coated pellets in dogs, Chem. Pharm. Bull. 56 (2008) 1118-1125.

6. H. Wei, F. Li-Fan, B. Xiang, L. Chun-Lei, D. Qing, C. Yong-Zhen and C. De-Ying, An investigation into the characteristics of chitosan/Kollicoat SR30D free films for colonic drug delivery, Eur. J. Pharm. Biopharm. 72 (2009) 266-274; DOI: 10.1016/j.ejpb.2008.10.017.

7. Z. Warkely, J. T. Fell, D. Attwood and D. Parkins, Pectin/ethyl cellulose film coating formulation for colonic drug delivery, Pharm. Res. 13 (1996) 1210-1212; DOI: 10.1023/A:1016016404404.

8. G. D. Beretta, L. Milesi, M. A. Pessi, S. Mosconi and R. Labianca, Adjuvant treatment of colorectal cancer, Surg. Oncol. 13 (2004) 63-73; DOI: 10.3322/canjclin.57.3.168.

9. K. Ciftci and M. J. Groves, Delivery of antitumor compounds to the rat colon: In vitro and in vivo evaluation, Int. J. Pharm. 145 (1996) 157-164; DOI: 10.1016/S0378-5173(96)04764-3.

10. V. R. Sinha, J. R. Bhinge, R. Kumria and M. Kumar, Development of pulsatile systems for targeted drug delivery of celecoxib for prophylaxis of colorectal cancer, Drug Deliv. 3 (2006) 221-225; DOI: 10.1080/10717540500309180.

11. United States Pharmacopoeia XXXII, National Formulary XXVII, Asian Edition USP, Convention, Rockville (M. D.) Volume 1, 2009. p. 263.

12. T. Higuchi, Rate of release of medications from ointment bases containing drugs in suspension, J. Pharm. Sci. 50 (1961) 874-875; DOI: 10.1002/jps.2600501018/pdf.

13. R. W. Korsemeyer, R. Gurny, E. Doelker, P. Buri and N. A. Peppas, Mechanisms of potasssiun chloride release from compressed, hydrophilic, polymeric matrices: effect of entrapped air, J. Pharm. Sci. 72 (1983) 1189-1191. DOI: 10.1002/jps.2600721021.

14. A. W. Hixon and J. H. Crowell, Dependence of reaction velocity upon surface and agitation, Ind. Eng. Chem. 23 (1931) 923-931; DOI: 10.1021/ie50260a018.

15. Y. X. Bi, H. Sunada, Y. Yonezawa and K. Danjo, Evaluation of rapidly disintegrating tablets prepared by direct compression method, Drug Dev. Ind. Pharm. 25 (1999) 571-581; DOI: 10.1081/ DDC-100102211.

16. M. Jivraj, L. G. Martini and C. M. Thomson, An overview of the different excipients useful for the direct compression of tablets, Pharm. Sci. Tech. Today 3 (2000) 58-63; DOI: 10.1016/S1461-5347 (99)00237-0.

17. S. Risk, D. Duru, D. Gaudy and M. Jacob, Natural polymer hydrophilic matrix: influencing drug release factors, Drug Dev. Ind. Pharm. 16 (1994) 2563-2574; DOI: 10.3109/03639049409042660. 
R. V. Kumar and V. R. Sinha: Tailoring of drug delivery of 5-fluorouracil to the colon via a mixed film coated unit system, Acta Pharm. 61 (2011) 343-351.

$S A \check{Z} E T A K$

\section{Dizajniranje sustava isporuke 5-fluorouracila u kolon tabletama obloženima miješanim filmom}

RUCHITA V. KUMAR i VIVEK RANJAN SINHA

Cilj rada bio je pripraviti miješane filmove od etilceluloze i Eudragita S100 za isporuku 5-flourouracil (5-FU) u kolon. Jezgre tableta s 5-FU pripravljene su metodom izravne kompresije koristeći nevodenu otopinu etilceluloze/Eudragita S100 $(2-9 \%, \mathrm{~m} / \mathrm{m})$. Iz obloženih tableta proučavano je in vitro oslobađanje 5-FU koristeći spektrofotometrijsku analizu na $266 \mathrm{~nm}$. Oslobađanje lijeka iz obloženog sustava ovisilo je o debljini filma i sastavu jezgre tablete. Stvaranje kanala u ovojnici potaknuto je otapanjem frakcije s Eudragitom S 100 pri višem pH u debelom crijevu. Jače oslobađanje bilo je iz tableta s Avicelom kao punilom nego iz tableta s laktozom zahvaljujući kapilarnom djelovanju Avicela. Nadalje, pripravci sa superdezintegratorom (1 \%, $\mathrm{m} / \mathrm{m}$ Cross-PVP) i Avicelom oslobađali su približno 81,1 \% lijeka u vremenu koje je potrebno za prolaz tableta kroz kolon. Kinetička ispitivanja pokazuju da svi pripravci slijede kinetiku prvog reda. Razvijeni sustavi trebali bi biti pogodni za isporuku lijeka u kolon.

Ključne riječi: 5-flourouracil, etilceluloza, Eudragit-S100, krospolivinilpirolidon, laktoza, Avicel

University Institute of Pharmaceutical Sciences, Panjab University, Chandigarh-160014, India 